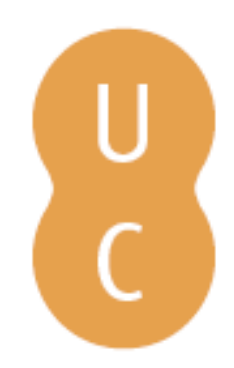

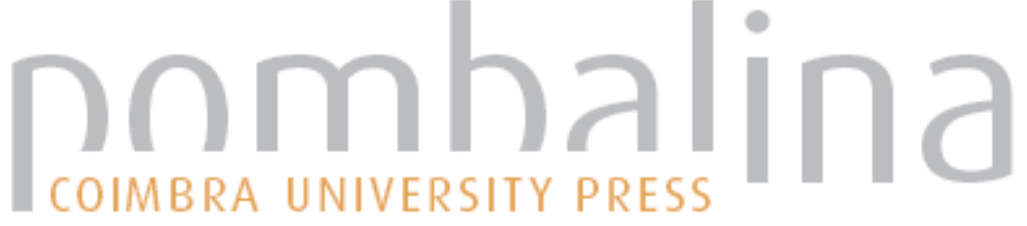

\section{Palimpsests and keener sounds}

\author{
Autor(es): $\quad$ Soares, Marta \\ Publicado por: Imprensa da Universidade de Coimbra \\ URL \\ DOI: $\quad$ DOI:https://doi.org./10.14195/978-989-26-1308-6_57 \\ Accessed : $\quad$ 26-Apr-2023 16:30:15
}

A navegação consulta e descarregamento dos títulos inseridos nas Bibliotecas Digitais UC Digitalis, UC Pombalina e UC Impactum, pressupõem a aceitação plena e sem reservas dos Termos e Condições de Uso destas Bibliotecas Digitais, disponíveis em https://digitalis.uc.pt/pt-pt/termos.

Conforme exposto nos referidos Termos e Condições de Uso, o descarregamento de títulos de acesso restrito requer uma licença válida de autorização devendo o utilizador aceder ao(s) documento(s) a partir de um endereço de IP da instituição detentora da supramencionada licença.

Ao utilizador é apenas permitido o descarregamento para uso pessoal, pelo que o emprego do(s) título(s) descarregado(s) para outro fim, designadamente comercial, carece de autorização do respetivo autor ou editor da obra.

Na medida em que todas as obras da UC Digitalis se encontram protegidas pelo Código do Direito de Autor e Direitos Conexos e demais legislação aplicável, toda a cópia, parcial ou total, deste documento, nos casos em que é legalmente admitida, deverá conter ou fazer-se acompanhar por este aviso.

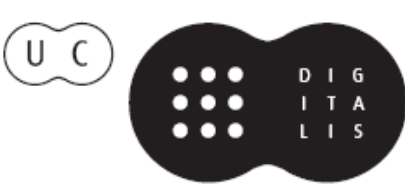





\section{PALIMPSESTSAND KEENER SOUNDS}

Marta Soares

The table wasn't round; it was a rectangle, yet it felt like a circle, inviting us to explore the world through the kaleidoscopic lens of poetry. I often find myself in this classroom, "Sala de Seminários do IENA", when I think about Professor Maria Irene and how it all began - my interest in American Studies, my craving for poetry, my deep admiration for my professor and advisor, for her remarkable encyclopedic knowledge, her rare zeal for detail, but especially her kindness and wit.

Those fortunate enough to know Professor Maria Irene personally are certainly aware of her dislike of excessive praise and applause. Yet, my words spring from an immense respect and, above all, gratitude for having been fortunate enough to have found such a generous guide and spirited friend.

The table wasn't round, yet it felt like a circle. Returning to "Sala dos Seminários" is an inevitable exercise of (mis)remembering, scratching the layers of a palimpsest made of cryptic words, soft old books, inquisitive young minds, carefully penned notes, and the commanding, yet kind presence of Professor Maria Irene. Poetry, with its "ghostlier demarcations, keener sounds," as superbly phrased by Wallace Stevens, was here a serious matter, a volatile gateway leading to knowledge and, more important, to never ending questions. 
The table wasn't round; it was a rectangle, yet it felt like a spiral: Emily Dickinson's volcanoes, William Carlos Williams's American grain, Hart Crane's "steeled Cognizance," Marianne Moore's feigned dislike of poetry, H.D.'s "thousand-petalled lily,” perpetually unfolding.

\section{Works cited}

Crane, H. The Complete Poems and Selected Letters and Prose of Hart Crane. London: Oxford University Press, 1972. Print.

Doolittle, H. Helen in Egypt. New York: New Directions Books, 1974. Print.

Stevens, W. The Collected Poems of Wallace Stevens. New York: Vintage Books, 1990. Print. 